\title{
K/Ar AGE DETERMINATIONS FROM WESTERN GREENLAND II. THE IVIGTUT REGION
}

\section{Ole Jørgensen}

The Ivigtut region is particularly remarkable for providing one of the best known examples of the transition between two Precambrian fold belts (Henriksen, in press; Allaart, Bridgwater and Henriksen, in press). In the north-east part of the area sediments and volcanics of the Ketilidian fold belt lie with a pronounced unconformity on gneisses and schists of the pre-Ketilidian basement. Traced southwards the Ketilidian supracrustal rocks show an increasing grade of metamorphism and the unconformity with the underlying basement is gradually obliterated as the basement becomes increasingly reactivated.

There is an important group of basic dykes which cut the preKetilidian basement but have not been found cutting the Ketilidian supracrustals. It has not yet been established whether these dykes are pre-Ketilidian or are contemporaneous with the volcanism which gave rise to the lavas and sills in the Ketilidian succession. However, they provide a ready means of recognising Ketilidian reactivation in the basement. In the north-west part of the Ivigtut region, away from the effects of Ketilidian plutonism, these dykes are fresh dolerites, but as the basement becomes increasingly reactivated to the southeast the dykes become increasingly altered to amphibolite and are eventually broken up and granite-veined.

Bondesen and Henriksen (1965) have described the changes in one such dyke as it is traced from an area where Ketilidian plutonism has had little effect (western Tôrnârssuk) to an area where the preKetilidian basement has been strongly reactivated during the Ketilidian (Arsuk Fjord). It should be noted that Bondesen's and Henriksen's paper went to press before the pre-Ketilidian age of the Ivigtut gneisses had been established, and their chronological terminology is therefore out-of-date. 
The present writer's aim has been to find out whether the transition from the pre-Ketilidian to the Ketilidian fold belt, which has been amply demonstrated in the field and under the microscope, would also be reflected in the K/Ar ages of this dyke and its surroundings. Age determinations have been carried out on samples of the dyke from western Tôrnârssuk where the plagioclase is almost unaltered although the pyroxene has been replaced by uralitic hornblende, and eastern Tôrnârssuk where the plagioclase has begun to recrystallise and new hornblende has begun to develop from the uralitic amphibole (Bondesen and Henriksen, 1965, pp. $21-24$ ). Samples of the country rocks from these localities were also dated, as well as a sample of gneiss on the north side of Arsuk Fjord where the dyke has completely recrystallised to a lineated amphibolite.

Because there are traces of Ketilidian metamorphism in western Tôrnârssuk the writer had to go farther north-west to the Qasigialik area to find material which might give the date of emplacement of the basic dykes and the age of the pre-Ketilidian basement. In the Qasigialik area NE-trending members of the group of dykes in question are fresh dolerites with well preserved primary pyroxene.

Results

Qasigialik area

$$
2550 \pm 80 \mathrm{~m} \cdot \mathrm{y} \text {. biotite }
$$

GGU 64239, south of the head of Qasigialik fjord. 65-13 Pegmatite in gneiss, $50 \mathrm{~m}$ from the fresh basic dyke described under GGU 64235 (below). This date falls in the range already obtained from the pre-Ketilidian gneiss complex of central West Greenland (Larsen and $\mathrm{M} \phi 1 \mathrm{ller}$, this report) and corresponds closely with the Kenoran peak in the Superior Province of the Canadian shield (Stockwell, 1964). 


\section{$2375 \pm 75 \mathrm{~m} \cdot \mathrm{y} \cdot$ biotite}

GGU 64236, south of the head of Qasigialik fjord.

Foliated biotite gneiss, $100 \mathrm{~m}$ from the fresh basic dyke described under GGU 64235 (below). This rock has been slightly up-dated, but not by more than about $150 \mathrm{~m}$. y.

\section{$1750 \pm 45 \mathrm{~m} \cdot \mathrm{y}$. biotite}

GGU 64235, south of the head of Qasigialik fjord. $65-14$ Contact-altered gneiss at the border of a fresh basic dyke. The dyke is a NE-trending member of the group of dykes described in the introduction. It is a completely fresh dolerite with a fine-grained margin. At the margin there is a $40 \mathrm{~cm}$ thick zone in which the country gneiss has been altered to a pale granitic rock with poor foliation. In places cuspate margins between dyke and altered gneiss indicate that this zone was plastic when the dyke was emplaced. From this one can reasonably expect the date of the contact-altered gneiss to give the date of intrusion of the dyke, especially as biotite in a pegmatite $50 \mathrm{~m}$ away shows no up-dating. However $100 \mathrm{~m}$ away the gneiss has been slightly up-dated, and it is possible that a similar up-dating has affected the contact-altered gneiss. Even if this is so the emplacement of the dyke is not likely to have taken place more than $1900 \mathrm{~m}$. y. ago, a figure which also gives the lower limit for the age of Ketilidian metamorphism.

Western Tônnârssuk

$$
1910 \pm 45 \mathrm{~m} \cdot \mathrm{y} \cdot \text { biotite }
$$

GGU 64200, Tôrnârssuk Havn.

Amphibolite band in pre-Ketilidian gneiss about $50 \mathrm{~m}$ from the E-W dyke described by Bondesen and Henriksen (1965). The date indicates an incomplete Ketilidian up-dating of the gneisses. The dyke here is only partially altered by Ketilidian metamorphism; its date is discussed below. 
$1725 \pm 60 \mathrm{~m} \cdot \mathrm{y}$. hornblende

GGU 64201, Tôrnârssuk Havn.

Fine-grained margin of the $\mathrm{E}-\mathrm{W}$ metadolerite dyke described by Bondesen and Henriksen (1965).

$$
1650 \pm 65 \mathrm{~m} . \mathrm{y} \text {. hornblende }
$$

GGU 64202, Tôrnârssuk Havn.

Metadolerite $3 \mathrm{~m}$ from the margin of the same dyke. In view of the experimental error the two dates obtained for this dyke cannot be treated as different. Although the plagioclase in the dyke is almost unaltered, all the original pyroxene has been altered to pale green uralitic hornblende enclosing bluish green acicular amphibole. Since hornblende forms less than $5 \%$ of these dykes where they are least altered, the hornblende dated in these samples must be regarded as having formed during Ketilidian metamorphism and the dates as reflecting this metamorphism.

It is possible that the difference in the dates obtained for the margin and inner part of this dyke is valid. Burwash et al. (1963) have noticed that in comparatively fresh diabase dykes the K/Ar age of the centre is sometimes less than that of the margins.

Eastern Tôrnârssuk

$$
\begin{aligned}
& 1690 \pm 70 \mathrm{~m} \cdot \mathrm{y} . \text { hornblende } \\
& 1570 \pm 35 \mathrm{~m} \cdot \mathrm{y} \text {. biotite }
\end{aligned}
$$

GGU 641 75, Kangerdluk, Tôrnârssuk.

Metadolerite. A sample from the same locality (GGU 32025) has been described by Bondesen and Henriksen (1965, pp. 23-24). Since hornblende is less susceptible to argon loss than biotite, the hornblende date is that most likely to give a correct indication of the date of the main Ketilidian metamorphism in this area, while the biotite date probably reflects the Sanerutian reactivation which is known to have taken place about $1600 \mathrm{~m}$. y. ago in the region to the south-east (Allaart, Bridgwater and Henriksen, in press). 
Arsuk Fjord

$1595 \pm 50 \mathrm{~m} . \mathrm{y} \cdot$ biotite

GGU 64079, $\mathrm{N}$ side of Arsuk fjord, almost due $\mathrm{N}$ of Ivigtut.

Biotite-rich gneiss about $50 \mathrm{~m}$ from the $\mathrm{E}-\mathrm{W}$ dyke which has been traced continuously from western Tôrnârssuk by Bondesen and Henriksen. Near Arsuk Fjord the dyke has been altered to a lineated amphibolite. The date on the country gneiss is a late-Ketilidian (Sanerutian) date, although the gneiss is a reworked pre-Ketilidian rock.

\section{References}

Allaart, J.H., Bridgwater, 'D. and Henriksen, N. (in press) The pre-Quaternary geology of South-West Greenland and its bearing on problems of correlation in the North Atlantic. Bull. Amer. Ass. Petrol. Geol.

Bondesen, E. and Henriksen, N. (1965) On some pre-Cambrian metadolerites from the central Ivigtut region SW Greenland. Medd. Grønland, Bd. 179, Nr. 2.

Burwash, R.A., Baadsgaard, H., Campbell, F.A., Cumming, G.L. and Folinsbee, R.E. (1963) Potassium-argon dates of diabase dyke systems, District of Mackenzie, N.W.T. Canad. Min. Metall. Bull., Vol. 66, 303-307.

Henriksen, N. (in press) Boundary relations between Precambrian fold belts in the Ivigtut region, South-West Greenland. Proc. geol. Ass. Canada, Centenary volume.

Stockwell, C.H. (1964) Age determinations and geological studies. Part II. Geological studies. Fourth report on structural provinces, orogenies, and time-classification of rocks of the Canadian Precambrian Shield. Geol. Surv. Canada, Paper 64-17, 1-21. 